\title{
Enhancing the Role of Geoconservation in Protected Area Management and Nature Conservation
}

\author{
John E. Gordon ${ }^{1} \cdot$ Roger Crofts $^{2} \cdot$ Enrique Díaz-Martínez $^{3} \cdot$ Kyung Sik Woo $^{4}$
}

Received: 20 December 2016 / Accepted: 28 June 2017 / Published online: 15 July 2017

(C) The Author(s) 2017. This article is an open access publication

\begin{abstract}
Acknowledgement by the International Union for the Conservation of Nature (IUCN) that geodiversity is part of natural diversity and geoheritage is part of natural heritage should help to strengthen the position and delivery of geoconservation through engagement with the wider nature conservation agenda. In particular, we identify six key areas offering opportunities to enhance the standing and mainstreaming of geoconservation: (1) integrating geoconservation principles in protected area management, including the promotion of geoheritage conservation across the full range of IUCN Protected Area Management Categories; (2) supporting biodiversity conservation and adaptation to climate change through the nature-based solutions approach and 'conserving nature's stage'; (3) contributing to natural capital and ecosystem services valuation; (4) contributing to conservation in the marine environment; (5) enhancing the connections between people, place, and nature and contributing to human well-being; and (6) promoting ecosystem stewardship and contributing to the achievement of the UN Sustainable Development Goals. Adoption of a more outward-looking approach should help to progress the integration of geoconservation within nature conservation, protected area planning and management, and broader environmental strategies and policies.
\end{abstract}

John E. Gordon

jeg4@st-andrews.ac.uk

1 School of Geography and Sustainable Development, University of St Andrews, St Andrews, Scotland KY16 9AL, UK

2 IUCN-WCPA Emeritus, Edinburgh, Scotland, UK

3 Geological Survey of Spain (IGME), Madrid, Spain

4 Department of Geology, Kangwon National University, Chuncheon, South Korea
Keywords Geodiversity · Geoheritage · Geoconservation principles $\cdot$ Ecosystem services $\cdot$ Nature conservation agenda

\section{Introduction}

Recognition of the wider values and relevance of geodiversity for nature and society is central to the development of geoconservation as an emerging geoscience (Henriques et al. 2011; Gordon et al. 2012; Gray 2013; Gray et al. 2013; Prosser et al. 2013; Crofts and Gordon 2015; Díaz-Martínez and Fernández-Martínez 2015). This recognition is crucial to establish geodiversity on a stronger and more equivalent footing with biodiversity (Brilha 2002; Crofts 2014, Crofts 2017). The purpose of this discussion paper is, first, to review recent developments within the International Union for the Conservation of Nature (IUCN) towards adopting a more integrated approach to nature conservation that includes the wider values of geodiversity and, second, to outline some key areas and directions that offer opportunities for developing such an integrated approach and the engagement of geoconservation with wider global agendas (Crofts 2017). We contend that a more outward-looking approach is necessary, both as part of developing a more formal and rigorous geoconservation science and in providing a platform to progress the mainstreaming of geoconservation within nature conservation, protected area planning and management, and broader environmental agendas, strategies, and policies (Crofts 2017; Gordon et al. in press). This extends, rather than replaces, the core activities associated with site-based geoconservation. In particular, we emphasise the importance of recognising the links between people, nature and the landscape in the management of protected areas, and the potential for linking geodiversity and biodiversity through 'conserving nature's stage', promoting the cultural values of geodiversity 
and engaging with ecosystem services. In doing so, we offer a perspective that explores the wider nature conservation agenda and highlights the relevance of geoconservation in addressing the key global challenges facing conservation in the coming decades (IUCN 2016a).

\section{IUCN Recognition of Geodiversity and Geoheritage}

The conservation of geodiversity and geoheritage is fundamental to a wide range of nature conservation issues and drivers (Table 1). However, these issues have been poorly addressed by the geoconservation community, particularly in terms of promoting the applications of relevant geoscience research (e.g. on climate change, geomorphological processes, links to biodiversity) in nature conservation and protected area management. The value of making these connections at a national level through strategic approaches to geoconservation has been advocated in the UK. This is exemplified by the adoption of Scotland's Geodiversity Charter (Scottish Geodiversity Forum 2013), the Geodiversity Charter for England (English Geodiversity Forum 2014), and the UK Geodiversity Action Plan (http://www.ukgap.org.uk/). However, the inputs of geodiversity, geoheritage, and their conservation (geoconservation) to, and recognition in, many of the key debates and strategy documents relating to the key issues in Table 1 have been very limited despite their clear relevance. Geodiversity and geoheritage are still poorly recognised and rarely integrated at a wider policy level and in protected area management generally.

At an international level, IUCN has played an important part in starting to redress this imbalance. IUCN is the world's largest nature conservation organisation, itself a conglomeration of government and charitable conservation bodies, and a global authority on biodiversity conservation, protected area management, and connecting people and nature. IUCN members must abide by IUCN's resolutions. In 2007, at the IUCN Protected Areas Summit, in Almeria, Spain, agreement was reached that 'protected areas should address a full range of

Table 1 Some key conservation policy areas and drivers offering opportunities to enhance the integration of geoconservation in the wider nature conservation agenda

- Integrating geoconservation principles in protected area management

- Supporting biodiversity conservation and adaptation to climate change through the nature-based solutions approach and 'conserving nature's stage'

- Contributing to natural capital and ecosystem services valuation

- Contributing to conservation in the marine environment

- Enhancing the connections between people, place, and nature and contributing to human well-being

- Promoting ecosystem stewardship and contributing to the achievement of the UN Sustainable Development Goals issues associated with 'diversity', including the need for protection of geological and soil diversity' (Dudley and Stolton 2008, p.194). Subsequently, in a significant development for the international recognition of geoconservation, IUCN Resolutions 4.040 (IUCN 2008), 5.048 (IUCN 2012) and 6.083 (IUCN 2016b) explicitly recognise that geodiversity is part of natural diversity and geoheritage is part of natural heritage. Notably, also, all three resolutions acknowledge the scientific, cultural, aesthetic, landscape, economic, and intrinsic values of geoheritage and the wider value and relevance of geodiversity in underpinning biological, cultural, and landscape diversity. They also state that both geodiversity and geoheritage must be considered in the assessment and management of natural areas. Formal recognition of the geodiversity component of protected areas was made in 2008 (Dudley 2008), and Resolutions 5.048 and 6.083 later called on the IUCN World Commission on Protected Areas (WCPA) to promote and support proper management of geoheritage in protected areas.

In 2014, the WCPA formally approved the establishment of a Geoheritage Specialist Group (GSG) (https:/www.iucn.org/ theme/protected-areas/wcpa/what-we-do/geoheritage). The GSG provides specialist advice and guidance on all aspects of geodiversity and geoheritage in relation to the establishment and management of protected areas, the integration of geoconservation into IUCN's programmes, and the promotion of better understanding of the links between geodiversity and biodiversity. It will also offer specialist geoheritage advice for the assessment of World Heritage Site nominations and develop new IUCN WCPA geoheritage guidance under Criterion (viii) for State Parties and assessors of World Heritage candidate sites, including facilitating relationships with international geological and geomorphological organisations. In addition, the GSG will act as a professional interface between IUCN and geoconservation stakeholders, such as UNESCO, NGOs, the mining industry, national administrations, and others.

The priority tasks of the GSG have included publication of a chapter on geoconservation for the first time in IUCN's Protected Area Governance and Management e-book (Crofts and Gordon 2015). This outlines the case for geoconservation in protected areas, the threats to geoheritage, and how geoheritage fits into the IUCN classification of Protected Area Management Categories (Table 2). Contrary to common belief, geoheritage conservation is not restricted to Category III (Natural Monument or Feature). All six Categories can include geoheritage interests and provide opportunities to integrate geoheritage and the wider landscape values of geodiversity much more closely in the conservation management of all protected areas. Geoparks are not a protected area category as such, although all of them contain important geosites as well as protected areas. The International Geoscience and Geoparks Programme of 
Table 2 IUCN Protected Area Management Categories (from Dudley 2008) and examples of geoheritage interests in the different categories (from Crofts and Gordon 2014)

\begin{tabular}{|c|c|}
\hline Category & Examples \\
\hline $\begin{array}{l}\text { Ia Strict nature reserve: strictly protected for biodiversity and also possibly geological/ } \\
\text { geomorphological features, where human visitation, use, and impacts are strictly } \\
\text { controlled and limited to ensure protection of the conservation values }\end{array}$ & $\begin{array}{l}\text { - Greenland Ice Cap, Greenland: ice cap and nunataks } \\
\text { - Geysir valley, Kronotsky Zapovednik, Russia: volcanic } \\
\text { features }\end{array}$ \\
\hline $\begin{array}{l}\text { Ib Wilderness area: usually large unmodified or slightly modified areas, retaining their } \\
\text { natural character and influence, without permanent or significant human habitation, } \\
\text { which are protected and managed so as to preserve their natural condition }\end{array}$ & $\begin{array}{l}\text { - Maspalomas Dunes Special Nature Reserve, Spain: } \\
\text { saltmarshes within Pleistocene dunes } \\
\text { - Noatak Wilderness, Alaska, USA: river basin }\end{array}$ \\
\hline $\begin{array}{l}\text { II National park: large natural or near natural areas set aside to protect large-scale } \\
\text { ecological processes, along with the complement of species and ecosystem } \\
\text { characteristic of the area, which also provide a foundation for environmentally and } \\
\text { culturally compatible spiritual, scientific, educational, recreational, and visitor } \\
\text { opportunities }\end{array}$ & $\begin{array}{l}\text { - Grand Canyon National Park, USA: stratigraphic record and } \\
\text { arid-land erosion } \\
\text { - Krkonoše/Karkonosze National Parks, Czech } \\
\text { Republic/Poland: periglacial landforms and } \\
\text { geodiversity-biodiversity relationships }\end{array}$ \\
\hline $\begin{array}{l}\text { III Natural monument or feature: areas set aside to protect a specific natural monument, } \\
\text { which can be a landform, sea mount, submarine cavern, and geological feature such as } \\
\text { a cave or even a living feature such as an ancient grove }\end{array}$ & $\begin{array}{l}\text { - Jenolan Karst Conservation Reserve, Australia: karst system } \\
\text { - Bosques Petrificados, Argentina: petrified forest }\end{array}$ \\
\hline $\begin{array}{l}\text { IV Habitat/species management area: areas to protect particular species or habitats where } \\
\text { management reflects this priority. Many will need regular, active interventions to } \\
\text { address the requirements of particular species or to maintain habitats, but this is not a } \\
\text { requirement of the category }\end{array}$ & $\begin{array}{l}\text { - Montserrat Mountain Partial Natural Reserve, Spain: } \\
\text { sedimentary rocks, caves and mountain erosion forms } \\
\text { - Lord Howe Marine Park, Australia: volcanic seamount }\end{array}$ \\
\hline $\begin{array}{l}\text { V Protected landscape/seascape: where the interaction of people and nature over time has } \\
\text { produced an area of distinct character with significant ecological, biological, cultural, } \\
\text { and scenic value and where safeguarding the integrity of this interaction is vital to } \\
\text { protecting and sustaining the area and its associated nature conservation and other } \\
\text { values }\end{array}$ & $\begin{array}{l}\text { - Cairngorms National Park, UK: Earth history and modern } \\
\text { geomorphological processes } \\
\text { - Lyngsalpan landscape protected area, Norway: alpine } \\
\text { mountains with glaciers and associated landforms }\end{array}$ \\
\hline $\begin{array}{l}\text { VI Protected area with sustainable use of natural resources: areas which conserve } \\
\text { ecosystems and habitats, together with associated cultural values and traditional } \\
\text { natural resource management systems. They are generally large, with most of the area } \\
\text { in a natural condition, where a proportion is under sustainable natural resource } \\
\text { management and where low-level non-industrial use of natural resources compatible } \\
\text { with nature conservation is seen as one of the main aims }\end{array}$ & $\begin{array}{l}\text { - Nublo Rural Park, Spain: volcanology and geomorphology } \\
\text { - Sečovlje Salina Nature Park, Slovenia: salt extraction }\end{array}$ \\
\hline
\end{tabular}

UNESCO therefore provides an international framework to conserve and enhance geoheritage under sustainable use strategies, as does the UNESCO World Heritage List. Recognising the integrity of nature and the interdependency of geoconservation and biodiversity conservation should be a common goal in protected area management founded on an ecosystem approach, as advocated under the Convention on Biological Diversity (CBD) ( 1992).

The preparation by the GSG of a 'Best Practice Guideline on Geoheritage Conservation in Protected Areas' (Crofts et al. in prep.) will provide more detailed practical management guidance and case studies to help build the capacity of protected areas' staff to deal effectively with conserving geoheritage. It will draw on expert input from across the global geoconservation community, addressing the need for geoheritage conservation, management principles, and best practice examples dealing with threats and communication. Development of more integrated approaches to the management of protected areas requires not only established guidelines for the protection of geosites but also the effective application of geoconservation principles that apply more widely to the sustainable management of natural systems (Crofts and Gordon 2014, 2015).
Reflecting these developments, Crofts and Gordon (2015) argued that geoconservation contributes to the functioning of healthy ecosystems and the services they provide. They emphasised the intrinsic, scientific, educational, cultural, aesthetic, and ecological/ecosystem values of geodiversity. They also highlighted the importance of integrating geoconservation into the management of all six IUCN Protected Area Management Categories, as part of an ecosystem approach that recognises the values and integrity of both abiotic and biotic processes in nature conservation. By acknowledging the value of geodiversity and geoheritage in their own right, such an approach benefits both biodiversity and geodiversity, and thus overall natural diversity.

The outcomes of the IUCN World Parks Congress in Sydney in 2014 (IUCN 2014) and the World Conservation Congress (WCC) in Hawai'i in 2016 (IUCN 2016a) highlighted the importance of protected areas for conserving nature and for their role in offering natural solutions to global issues, in particular: (1) the threats to biodiversity from habitat loss, climate change, and unsustainable exploitation; (2) the significance of the world's oceans for biodiversity and sustainable 
livelihoods; (3) the role of protected areas and other ecosystem-based approaches in providing natural solutions for global challenges, and particularly solutions for conservation and sustainability that combine traditional wisdom and modern knowledge; and (4) the need to engage a broader spectrum of stakeholders in conservation action, while at the same time benefiting human health and well-being (IUCN 2016a; MacKinnon and Londoño 2016). To meet these challenges, and following 'The Promise of Sydney' (IUCN 2014), the 2017-2020 IUCN Programme approved during the WCC in Hawai'i has three main areas: (1) valuing and conserving nature; (2) promoting and supporting effective and equitable governance of natural resources; and (3) deploying naturebased solutions to address societal challenges including climate change, food security, and economic and social development. Although attempts by geoheritage experts to make amendments to the wording of the draft IUCN Programme to specifically include geodiversity were unsuccessful, the use of the word 'nature' is inclusive of geodiversity as part of the nature conservation effort (IUCN 2012). Nevertheless, in the future, greater effort should be made by the geoconservation community to engage at an earlier stage in making an input to the IUCN programme development process to ensure recognition of geodiversity and geoheritage and their direct relevance for addressing the future challenges for nature conservation.

The WCPA Work Programme 2017-2020 will prioritise a number of key areas (MacKinnon and Londoño 2016), all of which provide opportunities for geoconservation engagement:

- Managing and enhancing protected areas (terrestrial, freshwater, and marine) to halt biodiversity loss and meet Aichi Target 11 set out in the CBD Strategic Plan for Biodiversity 2011-2020 (Convention on Biological Diversity 2010)

- Strengthening work on governance across all categories of protected areas

- Mainstreaming protected areas as natural solutions to existing and emerging global challenges, such as climate change, disaster risk reduction, food and water security, and exploring and promoting linkages between protected areas and spiritual, physical, and mental health and

- Helping to define post-2020 biodiversity targets and promoting protected areas as a valuable tool to achieve the UN Sustainable Development Goals (United Nations 2015a).

There is also a strong emphasis on building outreach and communication to reconnect people with nature and engage a broader constituency in conservation, for example through the \#NatureforAll programme (MacKinnon and Londoño 2016). This is a theme that closely aligns with geoconservation activities (Crofts 2017).
Integrating Geoconservation Principles in Protected Area Management

Promoting the adoption of key guiding principles for geoconservation (Table 3) is fundamental to implementing a more holistic approach in practice and in mainstreaming geoconservation into nature conservation and protected area planning and management. These principles should be an integral consideration in the rationales and management objectives for all six IUCN Protected Area Management Categories and form an essential part of an ecosystem approach in the wider landscape. These principles may be summarised as follows.

First, the wider values of geodiversity and geoheritage should be recognised, including cultural, aesthetic, and ecological values as well as those for science, education, and tourism that commonly underpin different geoheritage valuation systems (e.g. Brilha 2016; Reynard et al. 2016). These values have intrinsic (for their own or nature's sake independent of human values), instrumental or utilitarian (for humans' sake and use), and relational (including eudaimonic or human well-being) components (Gordon et al. in press). Protection of these values should be progressed across the full range of IUCN Protected Area Management Categories. As part of the development of a conservation management strategy for these areas, the completion of the key steps of geoheritage inventory, assessment of values and uses, conservation, risk assessment, monitoring, and, where appropriate, promotion through interpretation are a priority (Brilha 2005, 2016). This is particularly important where protected area managers may be unaware of the geodiversity of their areas and its geoheritage values.

Table 3 Geoconservation principles (modified from Crofts and Gordon 2014, 2015)

1. The multiple values of geodiversity and geoheritage should be recognised.

2. Effective geoconservation requires a systematic approach to all aspects of site identification and management.

3. Management of natural systems should 'work with nature'.

4. Natural systems and processes should be managed in a spatially integrated manner.

5. The inevitability of natural change should be recognised.

6. The effects of global climate change should be considered and acted on.

7. The sensitivity of natural systems should be recognised and they should be managed within the limits of their capacity to absorb change.

8. Conservation management of active systems should be based on understanding the underlying abiotic processes.

9. Provision should be made for managing visitors at sensitive sites and the promotion of education and interpretation of the whole natural heritage.

10. The interaction and interdependency of geodiversity and biodiversity should be recognised in conservation management. 
Second, the most effective and sustainable way of managing natural systems involves 'working with nature'. This requires 'making space for nature' and natural processes and managing natural systems in a spatially integrated manner, recognising landscape-scale connectivity, the interdependencies between geodiversity and biodiversity, and the wider catchment-scale impacts that will arise from geological and geomorphological changes.

Third, it is important to accept the inevitability of natural change and consider the effects of active geological and geomorphological processes. This means that protected area design should not be static and that natural systems should be managed within the limits of their capacity to absorb change. This includes considering geomorphological sensitivity and potential tipping points that may result from climate change.

Fourth, the application of geoscience in protected area management requires learning from the past and applying knowledge of geological and geomorphological processes and landscape evolution, not to provide static baselines but to help understand the ranges of natural process variability and possible future trajectories of change.

Fifth, protected area management should include provision for management of visitors, particularly at sensitive sites, together with appropriate education and interpretation. This means that protected area managers should promote education and interpretation of the whole natural heritage of each protected area. Often, the number and quality of education and interpretation programmes incorporating geoheritage are rather limited, even when important geological and geomorphological features occur in the protected area.

Many of these principles align closely with the promotion by IUCN and others of the role of healthy ecosystems in providing effective nature-based solutions to climate change (Dudley et al. 2010; IUCN 2014, 2016a; Belokurov et al. 2016; Cohen-Shacham et al. 2016).

\section{Supporting Biodiversity Conservation and Adaptation to Climate Change}

By definition, ecosystems comprise biotic and abiotic components that form interacting systems (Tansley 1935; Convention on Biological Diversity 1992). In conjunction with climate, geodiversity provides the fundamental underpinning for biodiversity, both in terms of the physical template (substrates, landform mosaics, and soil formation) for habitats and species, as well as the essential biogeochemical and geomorphological processes (water flow regimes, sediment supply, erosion, and deposition) that drive key ecosystem functions (e.g. Jačková and Romportl 2008; Anderson and Ferree 2010; Thorp et al. 2010; Jones et al. 2011; Semeniuk et al. 2011; le Roux and Luoto 2014) (Fig. 1). From a modern ecosystem perspective, the unity of the abiotic and biotic components of nature is axiomatic: geodiversity is an integral part of ecosystems and natural capital, and the services and benefits they provide.

Recognising the interaction and interdependency of geodiversity and biodiversity in protected area management is relevant to mediating biodiversity loss and helping to deliver the CBD Aichi targets. Most habitats and species depend on the abiotic 'stage' on which they exist (Anderson and Ferree 2010), not only rare or specialised ones, and areas of high geodiversity and environmental heterogeneity tend to support high biodiversity (Parks and Mulligan 2010). This applies across a range of scales from global to fine scales (e.g. Soukupová et al. 1995; Barthlott et al. 2005; Najwer et al. 2016; Tukiainen et al. 2017). Geodiversity therefore underpins a range of macro- and micro-habitats that provide opportunities for enhanced species richness, as well as distinctive habitats that support rare or unique biota adapted to particular abiotic conditions (Hjort et al. 2015; Porembski et al. 2016).

Geodiversity also supports biodiversity adaptation to climate change (Groves et al. 2012; Anderson et al. 2014; Theobald et al. 2015). For example, areas with a high geodiversity provide a range of topographic and environmental mosaics, corridors, and elevational settings, including macro- and micro-refugia, that enable species to persist, adapt, or relocate (Fig. 1). Therefore, as well as enhancing management of geodiversity, 'conserving nature's stage' offers a coarse filter approach to conservation planning that can improve the design and management of protected area networks for biodiversity (Anderson and Ferree 2010; Beier and Brost 2010; Beier et al. 2015). In particular, where species and communities are likely to alter in response to climate change, the conservation of geodiverse, heterogeneous landscapes should underpin the development of robust protected area networks that help to maintain the resilience and adaptive capacity of biodiversity and sustain key ecosystem processes (Anderson et al. 2014, 2015; Comer et al. 2015). In the face of climate change, the delivery of long-term biodiversity targets may therefore be improved by maintaining geodiversity and the natural processes that enhance landscape heterogeneity (Brazier et al. 2012). This is recognised in the IUCN Best Practice Guideline on 'Adapting to Climate Change' (Gross et al. 2016). However, the abiotic 'stage' is not static and maintaining the integrity of natural abiotic processes as far as possible is also part of the process of enabling ecosystem evolution (Pressey et al. 2007; Prober and Dunlop 2011).

Geoconservation management also has a significant part to play in the application of nature-based solutions in addressing climate change. The importance of maintaining healthy ecosystems was recognised in the Paris Agreement adopted in December 2015 under the United Nations Framework Convention on Climate Change (United Nations 2015b). Terrestrial, coastal, and marine ecosystems all act as significant carbon sinks and reservoirs, and the conservation of soils, 


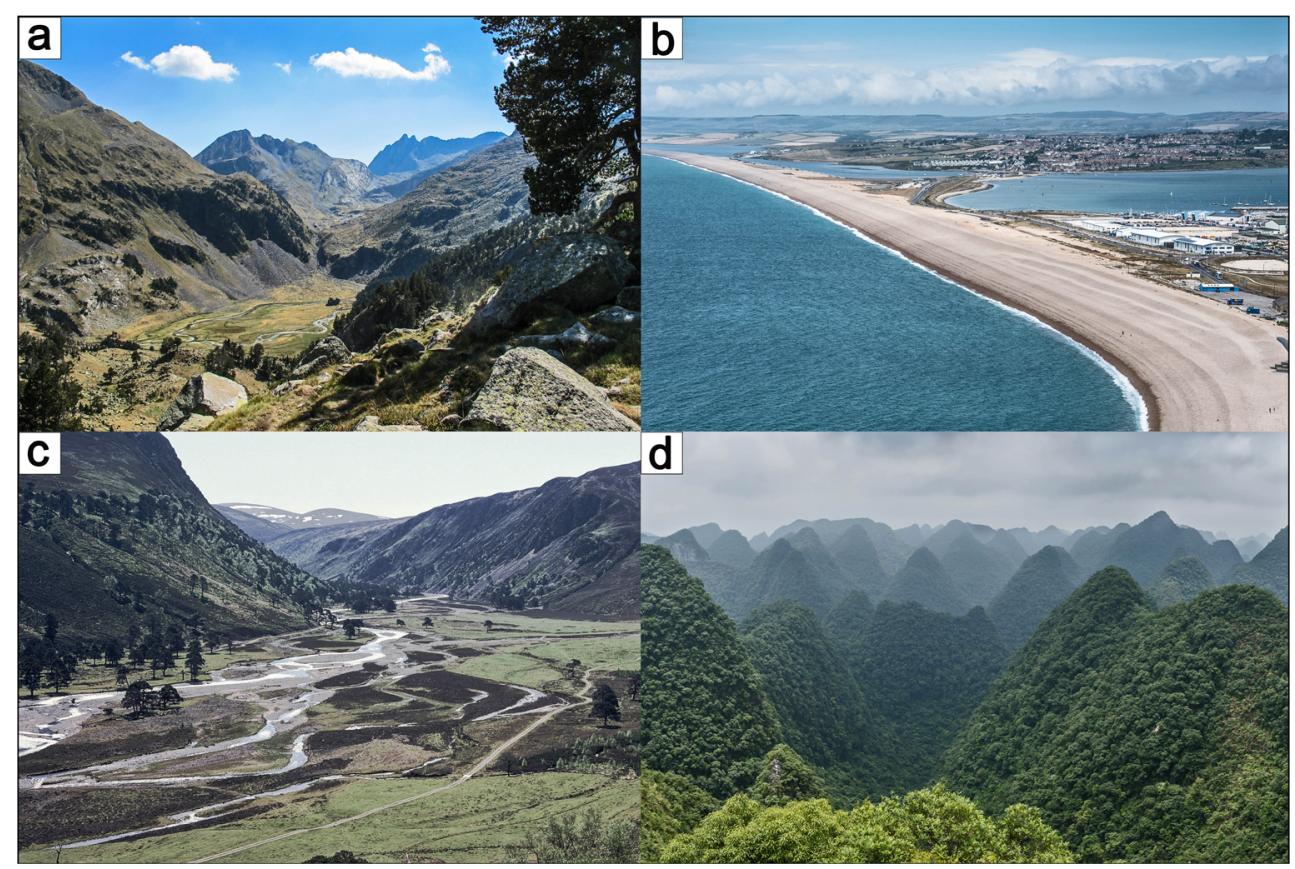

Fig. 1 Examples of links between geodiversity, biodiversity, and ecosystem services in different environments. a Posets-Maladeta Natural Park, Spain. In mountain areas, the complex patterns of stratigraphy, lithology, structural geology, soils, landform mosaics, and geomorphological processes generate a high geodiversity as well as geoheritage sites with high value, providing a heterogeneous and dynamic physical 'stage' that supports a high diversity of habitats and species across a range of scales, as well as other ecosystem services and benefits such as clean water, and opportunities for recreation, aesthetic appreciation, and artistic inspiration. b Chesil Beach and the Fleet Lagoon, part of the Jurassic Coast World Heritage Site, England. Coastal systems deliver a range of ecosystem services and benefits, including dynamic landforms and geomorphological processes for study

peatlands, and coastal and marine sediments is an important component of climate change mitigation. As well as supporting carbon sequestration, conservation management of soils and peatlands is integral to a multi-disciplinary approach to the prevention of land degradation, loss of water quality through erosion, and other critical ecosystem services (Agricultural University of Iceland 2005; Bigas et al. 2009; Adhikari and Hartemink 2016). Understanding abiotic processes and the application of this understanding are also fundamental in managing ecosystem adaptations to climate change (Gray et al. 2013). For example, the responses of geomorphological processes to climate change will have significant catchment-wide impacts on ecosystems and biodiversity, and with changes in one part of a system having knock-on effects elsewhere (Knight and Harrison 2013, 2014). Geoconservation-based solutions therefore have an important role in protected area management. They include 'working with nature' and 'making space for natural processes' or the restoration of natural processes. For example, at the coast and along river corridors (e.g. Hopkins et al. 2007; Opperman et al. 2009; Brazier et al. 2012; Jackson et al. 2012; Arkema and education, habitat provision for nature conservation, natural forms of coast defence and flood protection, and opportunities for recreation, aesthetic appreciation, and artistic inspiration. c River Feshie, Cairngorms National Park, Scotland. River corridors provide mosaics of geomorphological processes and dynamic habitats, water supplies, natural flood mitigation, and opportunities for recreation. d Huanjiang Karst, part of the South China Karst World Heritage Site, Guangxi Province, China. The geodiversity of the cone karst (fengcong) landscape supports a pristine, subtropical, humid-climate, mixed-forest ecosystem with vertical differentiation of forest types between the depressions and valleys and the tops of the cones. Numerous endemic plant and animal species are present. The karst landscape also has high cultural value

et al. 2013; Temmerman et al. 2013; Tessler et al. 2015), such solutions can help to provide resilience and reduce the vulnerability of protected areas and human communities to natural hazards such as coastal erosion, flooding, landslides, and soil erosion under more extreme climatic events (Dudley et al. 2010, 2015; Naylor et al. 2017).

\section{Natural Capital and Ecosystem Services Valuation}

The concepts of natural capital and ecosystem services have featured strongly in nature conservation policy particularly since the Millennium Ecosystem Assessment (2005). The valuation, both in economic and non-economic terms, of the services and benefits that nature provides to support human well-being can be an effective means to influence policy and to help increase public awareness of the value of nature conservation. Despite concerns about treating nature as a commodity and the difficulty of placing a monetary value on many cultural services (McCauley 2006; Silvertown 2015), 
ecosystem services provide a useful framework for communicating the importance of nature to the public and policy makers. The concept is gaining traction in international strategies, including the Aichi Biodiversity Targets in the Strategic Plan for Biodiversity 2011-2020 (Convention on Biological Diversity 2010) and the EU Biodiversity Strategy (European Commission 2011), as well as in national policies and programmes (e.g. Adams et al. 2014; Schaefer et al. 2015). It offers a means to highlight the wider benefits of nature and to examine the different ways in which people, knowingly or unknowingly, benefit from nature conservation.

Geodiversity confers many benefits (Fig. 1) across the full range of provisioning, regulating, cultural, and supporting categories of ecosystem services, including, for example, supply of freshwater, air quality and water regulation, natural hazard regulation, inspiration for literature and art, opportunities for recreation and geotourism, and support for habitats and species (Gordon and Barron 2013; Gray 2013). However, geodiversity has been under-represented or overlooked in the valuation of natural capital, and so far, there has been only limited exploration of ecosystem services in a geoconservation context (Gray 2011, 2013; Gray et al. 2013; van der Meulen et al. 2016; van Ree and van Beukering 2016). Greater engagement in this area by the geoscience and geoconservation communities, supported by case studies, would help to promote the value of geodiversity and geoheritage and their integration into environmental policy. Ecosystem services can be used to highlight the benefits of geodiversity across a wide range of policy areas including public health, the environment, recreation, the built environment, green infrastructure, sustainable rural development, tourism, and natural hazard risk management (Gordon and Barron 2012).

Integration of natural capital and ecosystem services into geoconservation strategies should be recognised as a utilitarian approach, and one that complements conservation of nature for its own sake (Hunter et al. 2014; Boulton et al. 2016; Pearson 2016). It requires mapping and assessments of the geodiversity components of ecosystem services in an area, their different conservation values, the analysis of benefits, and setting of conservation targets. Importantly, non-material as well as material values must be considered (Chan et al. 2016). More generally, there is a need for clear evidence that demonstrates how incorporating abiotic components into natural capital and ecosystem service assessments can lead to management outcomes that improve human well-being in both the short and long term. This means advancing understanding of the underlying biophysical mechanisms (Boulton et al. 2016) and providing the evidence base to support decision-making (Guerry et al. 2015; Lubchenco et al. 2015). It also requires developing metrics for assessing the multiple co-benefits of geoconservation in protected areas, as well as evaluating trade-offs between the services derived from biotic and abiotic nature (e.g. mineral extraction versus habitat support) and between economic and cultural values (e.g. between the landscape aesthetic value of a suite of glacial landforms and the economic value of the sand and gravel they contain) (Lele et al. 2013; Guerry et al. 2015; Saunders and Luck 2016).

\section{Marine Conservation}

Various international developments, including the OSPAR Convention (1992) and the EU Marine Strategy Framework Directive (2008), have highlighted the pressures on the marine environment and have set in place measures for the protection of marine habitats and species and the establishment of marine protected areas (Day et al. 2015). The World Parks Congress and the World Conservation Congress both reaffirmed the importance of marine conservation for biodiversity and people (IUCN 2014, 2016a; Wenzel et al. 2016). However, geoconservation in the marine environment has been largely overlooked, although there are a few exceptions, for example in the UK (Burek et al. 2013; Gordon et al. 2016). With the development of improved mapping of seabed features using new remote survey techniques, knowledge of seabed geomorphology has progressed greatly (Chiocci and Chivas 2014; Harris et al. 2014; Dowdeswell et al. 2016). At the same time, there is growing interest in seafloor mapping and the biophysical characterisation of the seabed to assist the development of marine protected areas based on the use of abiotic surrogates to represent biodiversity (Roff et al. 2003). The international GeoHab (Marine Geological and Biological Habitat Mapping) initiative (Todd and Greene 2007; Harris and Baker 2012), the MAREANO programme in Norway (Thorsnes et al. 2009; Buhl-Mortensen et al. 2015a, 2015b), and the MAREMAP in the UK (Diesing et al. 2014; Howe et al. 2015) are all contributing in this area. In addition, the integrity of the seafloor is now regarded as an important element of a healthy marine environment, for example under the EU Marine Strategy Framework Directive (Rice et al. 2012; Markus et al. 2015), which should help to ensure positive outcomes for geodiversity as well as biodiversity.

These developments in data availability, together with the use of biophysical indicators and characterisation of the seabed, offer significant potential to develop geoconservation in the marine environment, which is integrated with the conservation of seafloor habitats as part of an ecosystem approach. This is essential not only in view of the dependencies of habitats and species on geodiversity but also from a practical viewpoint given the difficulties in managing and monitoring the seabed and the resources required. To assist in prioritising resources, there is a need for better understanding of the sensitivity and vulnerability of different marine geodiversity 
interests and of the functional links between marine geodiversity and biodiversity (Gordon et al. 2016).

\section{Connecting People, Place, and Nature and Contributing to Human Well-Being}

There is now much greater acknowledgement that people are part of nature, leading to a growing focus in conservation policy on sustainable interactions between people and nature and the role of protected areas in contributing to human wellbeing at the same time as protecting nature (Mace 2014; Dudley et al. 2016; MacKinnon and Londoño 2016). This reflects recognition that the traditional separation of nature and culture in Western thinking is outdated (Feary et al. 2015). Connecting people with nature is a key outcome of the World Conservation Congress in 2016, in particular learning from traditional values and wisdom to gain a deeper understanding of sustainable solutions to conservation challenges (IUCN 2016a).

Geoconservation is well placed to address this issue. Many geosites have strong cultural and aesthetic associations, while many sacred natural sites are founded on particular rock formations, landforms, caves, or mineral outcrops where they need special management for their cultural values and where geoheritage is central to the whole reason for protection (Wild and McLeod 2008). Uluru is one well-known example but there are many more, less well-known ones, including many sacred mountains (Bernbaum and Price 2013). As for biodiversity (Schaaf and Lee 2006), therefore, sacred natural sites and cultural landscapes have a role to play in geoconservation (Kiernan 2015). This includes not only through World Heritage listing, but also through cross-cultural collaboration (Borrini-Feyerabend et al. 2004; Gavin et al. 2015) that involves local and indigenous people in geoconservation, with benefits of recognising and maintaining traditional knowledge and culture, while conserving and promoting geoheritage (Farsani et al. 2012; Tavares et al. 2015). The global growth of geotourism and geoparks offers a means to develop and promote the links between geoheritage and the cultural components of the landscape, as well as a means to enhance the visitor experience involving interpretation that encourages the rediscovery of a sense of wonder through the aesthetic and cultural connections of geoheritage (Martini 2000; Pralong 2006; Zgłobicki and Baran-Zgłobicka 2013; Gordon and Baker 2016). Such an approach, while retaining geology as a central focus, requires a more holistic integration of the geology, environment, culture, aesthetics, and heritage of an area (Martini et al. 2012; Stoffelen and Vanneste 2015). This may include etiological and euhemeristic connections expressed through geomythology, local folklore, and legends in terms of supernatural forces or the actions of mythical beings (Vitaliano 2007; Kirchner and Kubalíková 2015), or through various forms of iconography including rock art.

Geotourism is an important means to gain recognition for geoheritage and progressing geoconservation (Erikstad 2013). There is a substantial body of publications describing existing and potential geotourism provision at many sites around the world. However, there is an urgent need for a more rigorous approach, both to evaluate the expectations of visitors from different cultures and the kinds of activities and memorable experiences that will increase support for geoconservation, and to assess the effectiveness of geotourism in raising visitors' awareness and changing their behaviour. Much could be learned from engaging with the wider heritage and naturebased tourism research agenda (e.g. Kim et al. 2011; Packer et al. 2014; Healy et al. 2016). There are also challenges to develop the best practice management to enhance the visitor experience and protect the resource, while at the same time meeting the needs of local communities (Leung et al. 2015). Where available, traditional environmental knowledge should be integrated both in conservation management and in interpretation.

From a health and well-being viewpoint, geoparks have a valuable role in raising awareness of natural hazards and their risk management, since the principal interests of many geoparks involve natural hazards such as volcanoes and glaciers. The Shimabara Declaration (2012) from the 5th International Global Geoparks Network Conference addressed the role of geoparks in natural disasters, while the English Riviera Declaration from the 7th International Conference (UNESCO 2016) noted that UNESCO Global Geoparks can contribute to risk reduction and enhance disaster preparedness through education and sharing of good practice activities under the Sendai Framework for Disaster Risk Reduction (UNISDR 2015). Further, from an educational perspective, changes in dynamic geomorphological environments, such as mountains and coasts, have additional value in helping to raise awareness of climate change and natural hazards because the effects are often very apparent, for example in recent glacier recession (Reynard and Coratza 2016).

\section{Ecosystem Stewardship and Achievement of the UN Sustainable Development Goals}

The United Nations Sustainable Development Goals (SDGs) set out an agenda for action to end poverty, protect the planet, and ensure that all people enjoy peace and prosperity (United Nations 2015a). The geosciences have an essential contribution to make in delivering many of these goals (Lubchenco et al. 2015; Stewart and Gill 2017; Crofts 2017), including conservation and wise use of oceans (SDG14) and terrestrial ecosystems (SDG15), access to clean water (SDG6), health (SDG3), food security (SDG2), and climate action (SDG13). 
Several recognise the value of healthy natural systems, a key concern of geoconservation, and depend on the ecosystem services provided by geodiversity. For example, understanding of the maintenance of soil health and soil development and avoiding soil degradation and gross loss are fundamental if soil is to be recognised as a vital human and natural resource. In turn, therefore, sustainable use of soil is fundamental to healthy terrestrial ecosystems, clean water, human health, food security, and climate change mitigation. More generally, as part of the contribution of the geosciences, there is a need to explore how the principles of geoconservation can help to deliver sustainable use of Earth's natural resources and how they may be applied in the management of land, water, the coast, and the seafloor. This should include the wise use and management of natural capital and ecosystem services dependent on geodiversity as part of ecosystem stewardship that in turn recognises the interdependencies of human activity, well-being, and ecosystems (Chapin et al. 2010; Guerry et al. 2015).

\section{Conclusion}

As argued by Crofts (2017), in order to position geodiversity and geoheritage conservation more centrally in the nature conservation agenda, the geoconservation community must work to ensure that geodiversity and geoheritage conservation in protected areas gain more fundamental significance in local, national, and international agendas for nature, sustainable development, and human well-being. This requires that geoconservation science and practice engage not only with wider issues in the nature conservation agenda but also reach out proactively to offer sustainable, nature-based solutions to global problems. Addressing these issues will be challenging. There are fewer resources available for geoconservation than in other areas, poor understanding of how geoscience knowledge can contribute to the solution of complex management problems in dynamic natural systems that often extend beyond protected areas, lack of consideration of geoheritage in designing and managing protected area networks, and budget and staff cuts in many protected areas that limit employment of geoscience-trained staff.

However, the opportunities are now there to enhance geoconservation under the new focus on 'people and nature' and the 'conserving nature's stage' approaches and to generate multiple co-benefits both for geodiversity and biodiversity conservation and also for people, given the dependence of society on many services provided by geodiversity. In the face of human pressures and climate change, geodiversityinformed management strategies will be essential as part of an ecosystem approach to deliver nature conservation goals (including biodiversity targets) and benefits for people. This will require consideration of the geological and geomorphological setting of protected areas, their past history, process dynamics, and the functional links with biodiversity (i.e. their role as nature's 'stage'), as well as the value of geodiversity and geoheritage for human well-being. It is vital that geodiversity and geoheritage are fully integrated into the selection, management, and monitoring of all IUCN Protected Area Management Categories as part of an ecosystem approach that recognises the value of both abiotic and biotic processes in nature conservation and as part of natural capital (Matthews 2014; Peña et al. 2017). The broader discipline of geoconservation that is emerging is starting to recognise the wider intrinsic, cultural, aesthetic, and ecological values of geodiversity and geoheritage and their contributions to a range of benefits for nature and people. These values are now embedded in IUCN Resolutions, but more concerted action is required in practice to engage with the wider nature conservation community and to demonstrate the values and relevance of geoconservation in contributing to the evolving functions of protected areas. In particular, there is a need to develop the philosophical and theoretical basis of geoconservation, in order to enhance its scientific standing and thereby the ability of academics to attract research funding, and to translate this into actions, based on scientific evidence and case studies, that recognise the indivisibility of nature and of nature and people in protected area management.

Acknowledgements We thank the two reviewers for helpful comments that improved the manuscript.

Open Access This article is distributed under the terms of the Creative Commons Attribution 4.0 International License (http:// creativecommons.org/licenses/by/4.0/), which permits unrestricted use, distribution, and reproduction in any medium, provided you give appropriate credit to the original author(s) and the source, provide a link to the Creative Commons license, and indicate if changes were made.

\section{References}

Adams WM, Hodge ID, Sandbrook L (2014) New spaces for nature: the re-territorialisation of biodiversity conservation under neoliberalism in the UK. Trans Inst Br Geogr 39:574-588

Agricultural University of Iceland (2005) Strategies, science and law for the conservation of world soil resources. Agricultural University of Iceland Publications 4

Adhikari K, Hartemink AE (2016) Linking soils to ecosystem servicesa global review. Geoderma 262:101-111

Anderson MG, Ferree CE (2010) Conserving the stage: climate change and the geophysical underpinnings of species diversity. PLoS One 5(7):e11554. doi:10.1371/journal.pone.0011554

Anderson MG, Clark M, Sheldon AO (2014) Estimating climate resilience for conservation across geophysical settings. Conserv Biol 28: 959-970

Anderson MG, Comer PJ, Beier P, Lawler J, Schloss C, Buttrick S, Albano C, Faith DP (2015) Case studies of conservation plans that incorporate geodiversity. Conserv Biol 29:680-691

Arkema KK, Guanne G, Verutes G, Wood SA, Guerry A, Ruckelshaus M, Kareiva P, Lacayo M, Silver JM (2013) Coastal habitats shield 
people and property from sea-level rise and storms. Nat Clim Chang 3:913-918

Barthlott W, Mutke J, Rafiqpoor MD, Kier G, Kreft H (2005) Global centres of vascular plant diversity. Nova Acta Leopoldina 92:6183

Beier P, Brost B (2010) Use of land facets to plan for climate change: conserving the arenas, not the actors. Conserv Biol 24:701-710

Beier P, Hunter ML, Anderson MG (2015) Special section: conserving nature's stage. Conserv Biol 29:613-617

Belokurov A, Baskinas L, Biyo R, Clausen A, Dudley N, Guevara O, Lumanog J, Rakotondrazafy H, Ramahery V, Salao C, Stolton S, Zogib L (2016) Climate adaptation methodology for protected areas (CAMPA): coastal and marine. WWF, Gland

Bernbaum E, Price LW (2013) Attitudes toward mountains. In: Price MF, Byers AC, Friend DA, Kohler T, Price LW (eds) Mountain geography. Physical and human dimensions. University of California Press, Berkeley, pp 252-266

Bigas H, Gudbrandsson GI, Montanarella L, Arnalds A (eds) (2009) Soils, society and global change. Office for Official Publications of the European Communities, Luxembourg

Borrini-Feyerabend G, Pimbert M, Farvar T, Kothari A, Renard Y (2004) Sharing power: learning by doing in co-management of natural resources throughout the world. International Institute for Environment and Development (IIED) and the World Conservation Union (IUCN), Tehran, Iran

Boulton AJ, Ekebom J, Gíslason GM (2016) Integrating ecosystem services into conservation strategies for freshwater and marine habitats: a review. Aquat Conserv Mar Freshwat Ecosyst 26: 963-985

Brazier V, Bruneau PMC, Gordon JE, Rennie AF (2012) Making space for nature in a changing climate: the role of geodiversity in biodiversity conservation. Scott Geogr J 128:211-233

Brilha J (2002) Geoconservation and protected areas. Environ Conserv 29:273-276

Brilha J (2005) Património Geológico e Geoconservação: a Conservação da Natureza na sua Vertente Geológica. Palimage Editores, Viseu

Brilha J (2016) Inventory and quantitative assessment of geosites and geodiversity sites: a review. Geoheritage 8:119-134

Buhl-Mortensen L, Hodnesdal H, Thorsnes T (eds) (2015a) The Norwegian sea floor-new knowledge from MAREANO for ecosystem-based management. Norges Geologiske Undersøkelse, Trondheim

Buhl-Mortensen L, Buhl-Mortensen P, Dolan MFJ, Holte B (2015b) The MAREANO programme - a full coverage mapping of the Norwegian off-shore benthic environment and fauna. Mar Biol Res 11:4-17

Burek CV, Ellis NV, Evans DH, Hart MB, Larwood JG (2013) Marine geoconservation in the United Kingdom. Proc Geol Assoc 124:581-592

Chan KMA, Balvanera P, Benessaiah K, Chapman M, Díaz S, Gómez-Baggethun E, Gould R, Hannahs N, Jax K, Klain S, Luck GW, Martin-López B, Muraca B, Norton B, Ott K, Pascual U, Satterfield T, Tadaki M, Taggart J, Turner N (2016) Why protect nature? Rethinking values and the environment. PNAS 113:1462-1465

Chapin FS III, Carpenter SR, Kofinas GP, Folke C, Abel N, Clark WC, Olsson P, Stafford Smith DM, Walker B, Young OR, Berkes F, Biggs R, Grove JM, Naylor RL, Pinkerton E, Steffen W, Swanson FJ (2010) Ecosystem stewardship: sustainability strategies for a rapidly changing planet. Trends Ecol Evol 25:241-249

Chiocci FL, Chivas AR (eds) (2014) Continental shelves of the world: their evolution during the last glacio-eustatic cycle. Geolog Soc Lond Memoirs 41

Cohen-Shacham E, Walters G, Janzen C, Maginnis S (eds) (2016) Nature-based solutions to address global societal challenges. IUCN, Gland
Comer PJ, Pressey RL, Hunter ML, Schloss CA, Buttrick SC, Heller NE, Tirpak JM, Faith DP, Cross MS, Shaffer ML (2015) Incorporating geodiversity into conservation decisions. Conserv Biol 29:692-701

Convention on Biological Diversity (1992) Convention on biological diversity. UNEP-CBD, Montreal. Available at: https://www.cbd. int/ (accessed 29 May 2017)

Convention on Biological Diversity (2010) Strategic plan for biodiversity 2011-2020, including Aichi biodiversity targets. Available at: https:/www.cbd.int/sp/ (accessed 29 May 2017)

Crofts R (2014) Promoting geodiversity: learning lessons from biodiversity. Proc Geol Assoc 125:263-266

Crofts R (2017) Putting geoheritage conservation on all agendas. Geoheritage. doi: 10.1007/s12371-017-0239-y

Crofts R, Gordon JE (2014) Geoconservation in protected areas. Parks 20(2):61-76

Crofts R, Gordon JE (2015) Geoconservation in protected areas. In: Worboys GL, Lockwood M, Kothari A, Feary S, Pulsford I (eds) Protected area governance and management. ANU Press, Canberra, pp 531-567

Crofts R, Díaz-Martínez E, Gordon JE, Gray M, Tormey D, Worboys G (in prep.) Best practice guideline on geoheritage conservation in protected areas. Best practice protected area guidelines series no. XX. IUCN, Gland.

Day JC, Laffoley D, Zischka K (2015) Marine protected area management. In: Worboys GL, Lockwood M, Kothari A, Feary S, Pulsford I (eds) Protected area governance and management. ANU Press, Canberra, pp 609-650

Díaz-Martínez E, Fernández-Martínez E (2015) Geoheritage value: 1, fundamentals and significance (in Spanish). Cuadernos del Museo Geominero 18:13-18

Diesing M, Green SL, Stephens D, Lark RM, Stewart H, Dove D (2014) Mapping seabed sediments: comparison of manual, geostatistical, object-based image analysis and machine learning approaches. Cont Shelf Res 84:107-119

Dowdeswell JA, Canals M, Jakobsson M, Todd BJ, Dowdeswell EK, Hogan KA (eds) (2016) Atlas of submarine glacial landforms: modern, Quaternary and ancient. Geolog Soc Lond Memoirs 46

Dudley N (ed) (2008) Guidelines for applying protected area management categories. IUCN, Gland

Dudley N, Stolton S (eds) (2008) Defining protected areas: an international conference in Almeria, Spain. IUCN, Gland

Dudley N, Stolton S, Belokurov A, Krueger L, Lopoukhine N, MacKinnon K, Sandwith T, Sekhran N (eds) (2010) Natural solutions: protected areas helping people cope with climate change. IUCN-WCPA, TNC, UNDP, WCS, the World Bank and WWF, Gland, Switzerland, and Washington DC and New York, USA

Dudley N, Buyck C, Furuta N, Pedrot C, Renaud F, Sudmeier-Rieux K (2015) Protected areas as tools for disaster risk reduction. A handbook for practitioners. Ministry of Environment, Tokyo, Japan, and IUCN, Gland, Switzerland

Dudley N, Harrison IJ, Kettunen M, Madgwicke J, Mauerhofer V (2016) Natural solutions for water management of the future: freshwater protected areas at the 6th World Parks Congress. Aquat Conserv Mar Freshwat Ecosyst 26(Suppl. 1):121-132

English Geodiversity Forum (2014) Geodiversity charter for England Available at: http:/www.englishgeodiversityforum.org/Downloads/ Geodiversity\%20Charter\%20for\%20England.pdf (accessed 29 May 2017)

Erikstad L (2013) Geoheritage and geodiversity management — the questions for tomorrow. Proc Geol Assoc 124:713-719

European Commission (2011) Our Life Insurance, Our natural capital: an EU biodiversity strategy to 2020. COM(2011) 244 final. European Commission, Brussels. Available at: http://eur-lex.europa.eu/legalcontent/EN/TXT/?uri=CELEX:52011DC0244 (accessed 29 May 2017) 
Farsani NT, Coelho COA, da Costa CMM, de Carvalho CN (2012) Geoparks and geotourism. New approaches to sustainability for the 21st century. Brown Walker Press, Boca Raton

Feary S, Brown S, Marshall D, Lilley I, McKinnon R, Verschuuren B, Wild R (2015) Earth's cultural heritage. In: Worboys GL, Lockwood M, Kothari A, Feary S, Pulsford I (eds) Protected area governance and management. ANU Press, Canberra, pp 81-116

Gavin MC, McCarter J, Mead A, Berkes F, Stepp JR, Peterson D, Tang R (2015) Defining biocultural approaches to conservation. Trends Ecol Evol 30:140-145

Gordon JE, Baker M (2016) Appreciating geology and the physical landscape in Scotland: from tourism of awe to experiential re-engagement. In: Hose TA (ed), Appreciating physical landscapes: three hundred years of geotourism. The Geological Society, London, Special Publications 417, pp. 25-40

Gordon JE, Barron HF (2012) Valuing geodiversity and geoconservation: developing a more strategic ecosystem approach. Scott Geogr J 128: 278-297

Gordon JE, Barron HF (2013) The role of geodiversity in delivering ecosystem services and benefits in Scotland. Scott J Geol 49:41-58

Gordon JE, Barron HF, Hansom JD, Thomas MF (2012) Engaging with geodiversity - why it matters. Proc Geol Assoc 123:1-6

Gordon JE, Brooks AJ, Chaniotis PD, James BD, Kenyon NH, Leslie $\mathrm{AB}$, Long D, Rennie AF (2016) Progress in marine geoconservation in Scotland's seas: assessment of key interests and their contribution to marine protected area network planning. Proc Geol Assoc 127: 716-737

Gordon JE, Crofts R, Díaz-Martínez E (in press) Geoheritage conservation and environmental policies: retrospect and prospect. In: Reynard E, Brilha J (eds) Geoheritage. Assessment, protection and management. Elsevier, Amsterdam

Gray M (2011) Other nature: geodiversity and geosystem services. Environ Conserv 38:271-274

Gray M (2013) Geodiversity: valuing and conserving abiotic nature, 2nd edn. Wiley-Blackwell, Chichester

Gray M, Gordon JE, Brown EJ (2013) Geodiversity and the ecosystem approach: the contribution of geoscience in delivering integrated environmental management. Proc Geol Assoc 124:659-673

Gross JE, Woodley S, Welling LA, Watson JEM (2016) Adapting to climate change: guidance for protected area managers and planners, Best practice protected areas guidelines series no. 24. IUCN, Gland

Groves CR, Game ET, Anderson MG, Cross M, Enquist C, Ferdaña Z, Girvetz E, Gondor A, Hall KR, Higgins J, Marshall R, Popper K, Schill S, Shafer SL (2012) Incorporating climate change into systematic conservation planning. Biodivers Conserv 21:1651-1671

Guerry AD, Polasky S, Lubchenco J, Chaplin-Kramer R, Daily GC, Griffin R, Ruckelshaus M, Bateman IJ, Duraiappah A, Elmqvist T, Feldman MW, Folke C, Hoekstra J, Kareiva PM, Keeler BL, Li S, McKenzie E, Ouyang Z, Reyers B, Ricketts TH, Rockström J, Tallis H, Vira B (2015) Natural capital and ecosystem services informing decisions: from promise to practice. PNAS 112:7348-7355

Harris PT, Baker EK (eds) (2012) Seafloor geomorphology as benthic habitat. GeoHAB atlas of seafloor geomorphic features and benthic habitats. Elsevier, Amsterdam

Harris PT, Macmillan-Lawler M, Rupp J, Bake EK (2014) Geomorphology of the oceans. Mar Geol 352:4-24

Healy N, van Riper CJ, Boyd S (2016) Low versus high intensity approaches to interpretive tourism planning: the case of the Cliffs of Moher, Ireland. Tour Manag 52:574-583

Henriques MH, Pena dos Reis R, Brilha J, Mota T (2011) Geoconservation as an emerging geoscience. Geoheritage 3:117-128

Hjort J, Gordon JE, Gray JM, Hunter ML (2015) Why geodiversity matters in valuing nature's stage. Conserv Biol 29:630-639

Hopkins JJ, Allison HM, Walmsley CA, Gaywood M, Thurgate G (2007) Conserving biodiversity in a changing climate: guidance on building capacity to adapt. Defra, London
Howe JA, Stevenson A, Gatliff R (2015) Seabed mapping for the 21st century - the Marine Environmental Mapping Programme (MAREMAP): preface. Earth Environ Sci Trans R Soc Edinb 105: 239-240

Hunter ML, Redford KH, Lindenmayer DB (2014) The complementary niches of anthropocentric and biocentric conservationists. Conserv Biol 28:641-645

IUCN (2008) Resolutions and recommendations adopted at the 4th IUCN World Conservation Congress. Resolution 4.040: conservation of geodiversity and geological heritage. IUCN, Gland. Available at: https://portals.iucn.org/library/node/44190 (accessed 29 May 2017)

IUCN (2012) Resolutions and recommendations, World Conservation Congress, Jeju, Republic of Korea, 6-15 September 2012, WCC2012-Res-048 valuing and conserving geoheritage within the IUCN Programme 2013-2016. IUCN, Gland. Available at: https://portals. iucn.org/library/node/44015 (accessed 29 May 2017)

IUCN (2014) IUCN World Parks Congress. The promise of Sydney. Available at: http://www.worldparkscongress.org/about/promise of_sydney.html (accessed 29 May 2017)

IUCN (2016a) IUCN World Conservation Congress. The Hawai'i commitments. Available at: https://portals.iucn.org/congress/hawaiicommitments (accessed 29 May 2017)

IUCN (2016b) Resolutions and recommendations, World Conservation Congress, Hawai'i, USA, 1-10 September 2016, WCC-2016-Res083. Conservation of moveable geological heritage. IUCN, Gland. Available at: https://portals.iucn.org/library/node/46500 (accessed 29 May 2017)

Jačková K, Romportl D (2008) The relationship between geodiversity and habitat richness in Šumava National Park and Křivoklátsko Pla (Czech Republic): a quantitative analytical approach. J Landsc Ecol 1:23-38

Jackson NL, Nordstrom KF, Feagin RA, Smith WK (2012) Coastal geomorphology and restoration. Geomorphology 199:1-7

Jones L, Angus S, Cooper A, Doody P, Everard M, Garbutt A, Gilchrist P, Hansom J, Nicholls R, Pye K, Ravenscroft N, Rees S, Rhind P, Whitehouse A (2011) Chapter 11: coastal margins. In: The UK National Ecosystem Assessment Technical Report. UNEPWCMC, Cambridge, pp 411-458

Kiernan K (2015) Landforms as sacred places: implications for geodiversity and geoheritage. Geoheritage 7:177-193

Kim AK, Aire D, Szivas E (2011) The multiple assessment of interpretation effectiveness: promoting visitors' environmental attitudes and behavior. J Travel Res 50:321-334

Kirchner K, Kubalíková L (2015) Geomythology: an useful tool for geoconservation and geotourism purposes. In: Fialová J, Pernicová D (eds) Public recreation and landscape protection - with man hand in hand! Czech Society of Landscape Engineers and Department of Landscape Management Faculty of Forestry and Wood Technology Mendel University in Brno, Brno, pp 68-74

Knight J, Harrison S (2013) The impacts of climate change on terrestrial Earth surface systems. Nat Clim Chang 3:24-29

Knight J, Harrison S (2014) Mountain glacial and paraglacial environments under global climate change: lessons from the past, future directions and policy implications. Geogr Ann 96A:245-264

Lele S, Springate-Baginski O, Lakerveld R, Deb D, Dash P (2013) Ecosystem services: origins, contributions, pitfalls and alternatives. Conserv Soc 11:343-358

le Roux PC, Luoto M (2014) Earth surface processes drive the richness, composition and occurrence of plant species in an arctic-alpine environment. J Veg Sci 25:45-54

Leung Y-F, Spenceley A, Hvenegaard G, Buckley R (2015) Tourism and visitor management in protected areas: guidelines for sustainability. Best practice protected area guidelines series no. XX. IUCN, Gland, Switzerland. Review copy [online]. Available at: https://iucn.oscar. ncsu.edu/mediawiki/index.php/Tourism_and_Visitor 
Management_in_Protected_Areas_-_Guidelines_for_Sustainability (accessed 29 May 2017)

Lubchenco J, Barner AK, Cerny-Chipman EB, Reimer JN (2015) Sustainability rooted in science. Nat Geosci 8:741-745

Mace GM (2014) Whose conservation? Science 345:1558-1560

MacKinnon K, Londoño JM (2016) Editorial: delivering the promise of Sydney: from Sydney to Hawai'i. Parks 22(2):7-10

McCauley D (2006) Selling out on nature. Nature 443:27-28

Markus T, Huhn K, Bischof K (2015) The quest for sea-floor integrity. Nat Geosci 8:163-164

Martini G (2000) Geological heritage and geo-tourism. In: Barettino D, Wimbledon WAP, Gallego E (eds) Geological heritage: its conservation and management. Instituto Tecnológico Geominero de España, Madrid, pp 147-156

Martini G, Alcalá L, Brilha J, Iantria L, Sá A, Tourtellot J (2012) Reflections about the geotourism concept. In: Sá AA, Rocha D, Paz A, Correia V (eds) Proceedings of the 11 European Geoparks Conference. AGA - Associação Geoparque Arouca, Arouca, pp $187-188$

Matthews TJ (2014) Integrating geoconservation and biodiversity conservation: theoretical foundations and conservation recommendations in a European Union context. Geoheritage 6:57-70

Millennium Ecosystem Assessment (2005) Ecosystems and human wellbeing: synthesis. Island Press, Washington DC

Najwer A, Borysiak J, Gudowicz J, Mazurek M, Zwoliński Z (2016) Geodiversity and biodiversity of the postglacial landscape (Dębnica River catchment, Poland). Quaestiones Geographicae 35: 5-28

Naylor LA, Spencer T, Lane SN, Darby SE, Magilligan FJ, Macklin MG, Möller I (2017) Stormy geomorphology: geomorphic contributions in an age of climate extremes. Earth Surf Process Landf 42:166-190

Opperman JJ, Galloway GE, Fargione J, Mount JF, Richter BD, Secchi S (2009) Sustainable floodplains through large-scale reconnection to rivers. Science 326:1487-1488

Packer J, Ballantyne R, Hughes K (2014) Chinese and Australian tourists' attitudes to nature, animals and environmental issues: implications for the design of nature-based tourism experiences. Tour Manag 44: $101-107$

Parks KE, Mulligan M (2010) On the relationship between a resource based measure of geodiversity and broad scale biodiversity patterns. Biodivers Conserv 19:2751-2766

Pearson RG (2016) Reasons to conserve nature. Trends Ecol Evol 31: 366-371

Peña L, Monge-Ganuzas M, Onaindia M, Fernández de Manuel B, Mendia M (2017) A holistic approach including biological and geological criteria for integrative management in protected areas. Environ Manag 59:325-337

Porembski S, Silveira FAO, Fiedler PL, Watve A, Rabarimanarivo M, Kouame F, Hopper SD (2016) Worldwide destruction of inselbergs and related rock outcrops threatens a unique ecosystem. Biodivers Conserv 25:2827-2830

Pralong J-P (2006) Geotourism: a new form of tourism utilising natural landscapes and based on imagination and emotion. Tourism Revue 61(3):20-25

Pressey RL, Cabeza M, Watts ME, Cowling RM, Wilson KA (2007) Conservation planning in a changing world. Trends Ecol Evol 22: $583-592$

Prober SM, Dunlop M (2011) Climate change: a cause for new biodiversity conservation objectives but let's not throw the baby out with the bathwater. Ecol Restor Manage 12:2-3

Prosser CD, Brown EJ, Larwood JG, Bridgland DR (2013) Geoconservation for science and society - an agenda for the future. Proc Geol Assoc 124:561-567

Reynard E, Coratza P (2016) The importance of mountain geomorphosites for environmental education: examples from the
Italian Dolomites and the Swiss Alps. Acta Geographica Slovenica 56:291-303

Reynard E, Perret A, Bussard J, Grangier L, Martin S (2016) Integrated approach for the inventory and management of geomorphological heritage at the regional scale. Geoheritage 8:43-60

Rice J, Arvanitidis C, Borja A, Frid C, Hiddink JG, Krause J, Lorance P, Ragnarsson SÁ, Sköld M, Trabucco B, Enserink L, Norkko A (2012) Indicators for sea-floor integrity under the European Marine Strategy Framework Directive. Ecol Indic 12:174-184

Roff JC, Taylor ME, Laughren J (2003) Geophysical approaches to the classification, delineation and monitoring of marine habitats and their communities. Aquat Conserv Mar Freshwat Ecosyst 13:77-90

Saunders ME, Luck GW (2016) Limitations of the ecosystem services versus disservices dichotomy. Conserv Biol 30:1363-1365

Schaaf T, Lee C (2006) Conserving cultural and biological diversity: the role of sacred natural sites and cultural landscapes. UNESCO, Paris

Schaefer M, Goldman E, Bartuska AM, Sutton-Grier A, Lubchenco J (2015) Nature as capital: advancing and incorporating ecosystem services in United States federal policies and programs. PNAS 112:7383-7389

Scottish Geodiversity Forum (2013) Scotland's geodiversity charter Available at: http://scottishgeodiversityforum.org/charter/ (accessed 29 May 2017)

Semeniuk V, Semeniuk CA, Tauss C, Unno J, Brocx M (2011) Walpole and Nornalup inlets: landforms, stratigraphy, evolution, hydrology, water quality, biota, and geoheritage. Wetlands Research Association, Western Australian Museum, Perth, WA

Shimabara Declaration (2012) The Shimabara Declaration (2012) Available at: http:/jgc.geopark.jp/files/Shimabara\%20Declaration. pdf (accessed 29 May 2017)

Silvertown J (2015) Have ecosystem services been oversold? Trends Ecol Evol 30:641-648

Soukupová L, Kociánová M, Jeník J, Sekyra J (1995) Arctic-alpine tundra in the Krkonoše, the Sudetes. Opera Corcontica 32:5-88

Stewart IS, Gill JC (2017) Social geology —integrating sustainability concepts into Earth sciences. Proc Geol Assoc 128:165-172

Stoffelen A, Vanneste D (2015) An integrative geotourism approach: bridging conflicts in tourism landscape research. Tour Geogr 17: 544-560

Tansley AG (1935) The use and abuse of vegetational concepts and terms. Ecology 16:284-307

Tavares AO, Henriques MH, Domingos A, Bala A (2015) Community involvement in geoconservation: a conceptual approach based on the geoheritage of South Angola. Sustainability 7:4893-4918

Temmerman S, Meire P, Bouma TJ, Herman PMJ, Ysebaert T, De Vriend HJ (2013) Ecosystem-based coastal defence in the face of global change. Nature 504:79-83

Tessler ZD, Vörösmarty CJ, Grossberg M, Gladkova I, Aizenman H, Syvitski JPM, Foufoula-Georgiou E (2015) Profiling risk and sustainability in coastal deltas of the world. Science 349: 638-643

Theobald DM, Harrison-Atlas D, Monahan WB, Albano CM (2015) Ecologically-relevant maps of landforms and physiographic diversity for climate adaptation planning. PLoS One 10(12):e0143619. doi:10.1371/journal.pone.0143619

Thorp JH, Flotemersch JE, Delong MD, Casper AF, Thoms MC, Ballantyne F, Williams BS, O'Neill BJ, Haase SH (2010) Linking ecosystem services, rehabilitation, and river hydrogeomorphology. Bioscience 60:67-74

Thorsnes T, Erikstad L, Dolan MFJ, Bellec V (2009) Submarine landscapes along the Lofoten-Vesterålen-Senja margin, northern Norway. Nor J Geol 89:5-16 
Todd BJ, Greene HG (2007) Mapping the seafloor for habitat characterization. Geol Assoc Canada, Special Publication 47

Tukiainen H, Bailey JJ, Field R, Kangas K, Hjort J (2017) Combining geodiversity with climate and topography to account for threatened species richness. Conserv Biol 31:364-375

UNESCO (2016) The English Riviera Declaration. 7th International Conference on UNESCO Global Geoparks, Torquay, English Riviera UNESCO Global Geopark, United Kingdom Available at: http:/www.unesco.org/new/fileadmin/MULTIMEDIA/HQ/SC/pdf/ The_English_Riviera_Declaration.pdf (accessed 29 May 2017)

UNISDR (2015) Sendai framework for disaster risk reduction 20152030. The United Nations Office for Disaster Reduction, Geneva, Switzerland. Available at: http://www.unisdr.org/we/inform/ publications/43291 (accessed 29 May 2017)

United Nations (2015a) Transforming our world: the 2030 agenda for sustainable development. Resolution 70/1adopted by the General Assembly on 25 September 2015. Available at: https:// sustainabledevelopment.un.org/post2015/transformingourworld (accessed 29 May 2017)
United Nations (2015b) The United Nations framework convention on climate change. The Paris Agreement. Available at: http://unfccc.int/ paris_agreement/items/9485.php (accessed 29 May 2017)

van der Meulen ES, Braat LC, Brils JM (2016) Abiotic flows should be inherent part of ecosystem services classification. Ecosystem Services 19:1-5

van Ree CCDF, van Beukering PJH (2016) Geosystem services: a concept in support of sustainable development of the subsurface. Ecosystem Services 20:30-36

Vitaliano DB (2007) Geomythology: geological origins of myths and legends. In: Piccardi L, Masse WB (eds) Myth and geology. The Geological Society, London, Special Publications 273, pp 1-7

Wild R, McLeod C (2008) Sacred natural sites: guidelines for protected area managers. IUCN, Gland

Wenzel L, Laffoley D, Caillaud A, Zuccarino-Crowe C (2016) Protecting the World's ocean - the promise of Sydney. Aquat Conserv Mar Freshwat Ecosyst 26:251-255

Zgłobicki W, Baran-Zgłobicka B (2013) Geomorphological heritage as a tourist attraction. A case study in Lubelskie Province, SE Poland. Geoheritage 5:137-149 